\title{
Interferons in the Therapy of Severe Coronavirus Infections: A Critical Analysis and Recollection of a Forgotten Therapeutic Regimen with Interferon Beta
}

\author{
Authors \\ Josef Brzoska1, ${ }^{*}$, Harald von Eick2,*, Manfred Hündgen ${ }^{3, *}$ \\ Affiliations \\ 1 Linical Europe GmbH, Frankfurt, Germany \\ 2 CTI Clinical Trial and Consulting Services Europe GmbH, \\ Ulm, Germany \\ 3 Rentschler Biotechnologie GmbH, Laupheim, Germany \\ * Last affiliations prior to retirement
}

\section{Key words}

antiviral drugs, cytokines, drug research, human pharmacology, infectious diseases, immunopharmacology, SARS, MERS,

COVID-19, SARS-CoV-2

received 24.03.2020

accepted 29.04.2020

\section{Bibliography}

DOI https://doi.org/10.1055/a-1170-4395

Published online: 22.5 .2020

Drug Res 2020; 70: 291-297

(c) Georg Thieme Verlag KG Stuttgart · New York

ISSN 2194-9379

\author{
Correspondence \\ Josef Brzoska \\ Hopfenweg 2/1 \\ D-88471 Laupheim \\ Germany \\ Tel.: +497392 7878, Fax: + 4973927878 \\ josef.brzoska@t-online.de
}

\begin{abstract}
The pharmacological and immunological properties of interferons, especially those of interferon beta, and the corresponding treatment strategies are described, and the results of studies with different interferons in coronavirus infections are analysed. Furthermore, the data obtained with high-dosed native interferon beta in life-threatening acute viral diseases as well as the results of clinical pilot studies with high-dosed recombinant interferon beta-1a are provided because they serve as the rationale for the proposed therapeutic regimen to be applied in acute viral infections. This regimen differs from those approved for treatment of multiple sclerosis and consists of interferon beta-1a administered as a 24 hour intravenous infusion at a daily dose of up to $90 \mu \mathrm{g}$ for 3-5 consecutive days. Since under this regimen transient severe side effects can occur, it is analysed which patients are suitable for this kind of treatment in general and if patients with severe coronavirus infections could also be treated accordingly.
\end{abstract}

\section{Introduction}

The outbreak of the recent respiratory syndrome COVID-19 caused by the novel coronavirus SARS-CoV-2 has spread from China to many countries in the world. On 11 March 2020 the World Health Organization (WHO) made the assessment that COVID-19 can be characterized as a pandemic [1]. Although most affected patients suffer from mild to moderate symptoms, the total number of fatal cases exceeds that of other coronavirus infections, severe acute respiratory syndrome (SARS) and Middle East respiratory syndrome (MERS), [2-4].

Regardless of the fact that currently numerous therapeutic options are under review, so far no effective therapy could be identi- fied [5-7]. Among others, interferons are considered as possible effective antiviral drugs against coronavirus infections.

\section{Properties of interferons and corresponding treatment strategies}

Interferons are (glyco-)proteins with antiviral activity. They are members of the cytokine family. Since they are expressed rapidly during the process of a viral infection they form an essential part of a very early and virus-unspecific host defense mechanism against multiple viruses [8]. Some viruses including coronaviruses are weak interferon inducers and hence hardly activate this natural defense mechanism of the body. An indicator of the importance of this interferon evasion strategy is the finding that in cell culture and ani- 
mal experiments interferons can strongly inhibit the replication of coronaviruses. There are still other defense mechanisms of the body so that most patients with a coronavirus infection recover after illness [9-12]. Thus, interferon therapy in coronavirus infections could be considered as a substitution of a compound which is not sufficiently produced by the body during these diseases. The clinical and pharmacological/immunological implications of the said interferon substitution in an acute coronavirus infection will be discussed below.

Beside their antiviral properties, interferons are characterized by antiproliferative activities relative to numerous malignant and non-malignant cells. Furthermore, they modulate cell differentiation and a variety of humoral and cellular immune functions. $[8,13-16]$. The role interferons play in immunity and autoimmunity is rather complex, not only protective but also pathogenic effects are described or discussed, respectively [11].

Based on their protein structures and cell-surface receptors, interferons are divided into type I interferons (several interferon alpha subtypes, interferon beta, interferon epsilon, interferon kappa, interferon omega), type II interferons (interferon gamma) and type III interferons (several interferon lambda subtypes). For more than 35 years interferons have been produced in large quantities for clinical application via human diploid cell cultures (native interferons) and more frequently via non-human host cells such as E. coli and Chinese hamster ovary $(\mathrm{CHO})$ cells using recombinant DNA technology (recombinant interferons). Various interferons are available as approved drugs [15-19]. Because interferons are to a large extent species-specific or have "defined host-ranges" [20], respectively, the pharmacological effects of human interferons can expediently and reliably be investigated only in man, in non-human primate models and in human cell cultures.

During decades of clinical experience with various interferon preparations in numerous diseases clinicians had to learn that very different dosing regimens and routes of administration are required in order to exploit a specific pharmacodynamic activity of a certain interferon preparation in the treatment of a particular disease [14-26]. High doses of interferons must be applied in order to create high serum levels which are probably essential for treatment focused on antiviral or antiproliferative interferon activities. In contrast, immunomodulation is often achieved with low doses whereby opposing effects (activation or inhibition) can be observed depending on a variety of conditions $[13,14,27,28]$. Interferon beta, due to its stronger hydrophobicity, has a much higher tissue affinity compared to interferon alpha. Intramuscular (IM) or subcutaneous (SC) injections of interferon beta result in only low serum levels. Whenever high serum concentration of interferon beta is targeted, this cytokine requires the intravenous (IV) route of administration. High serum levels are, however, not required in order to exploit the immunomodulating potential of interferon beta since corresponding effects can be observed with IM or SC administration of even low doses [22, 27, 29-33].

In order to prolong the elimination half-life and thus to decrease the necessary administration frequency, some companies have developed pegylated forms of their respective interferon preparations. Such preparations are available for human use since the early 2000s $[18,34,35]$.
Whenever feasible and appropriate, a local/topical application of the interferons should be considered since a relatively high local concentration of interferon can be achieved with a relatively low but therapeutically effective dose, and hence systemic adverse drug reactions can be reduced or completely avoided $[14,18,36]$.

The therapeutic areas where interferons are used cover acute and chronic viral infections, malignancies and immune disorders [15-26]. Due to the variety of indications, it is not surprising that a regimen successfully used in one disease can be ineffective in another. There are approved therapeutic regimens for recombinant interferon alfa preparations concerning chronic viral hepatitis B and $C$ and some malignant diseases. Recombinant interferon beta preparations are only approved for the treatment of multiple sclerosis. For the experimental treatment of other diseases including acute viral diseases, the use of other dose regimens of interferon beta-1a is suggested [22].

\section{Preclinical and clinical studies of interferons in coronavirus infections}

Interferons can inhibit the replication of coronaviruses in vitro and show clinical effects in animal models [37-53]. In order to see if such promising results could also be achieved in a clinical setting, clinical studies using interferons, typically in combination with other antiviral drugs, were performed to treat SARS and MERS [54-59]. In these studies, only a minor or even no therapeutic benefit was observed, as outlined in review papers covering not only the aforementioned clinical studies but also several case reports [5, 60-64].

What could be the reason for the failure of interferons in SARS and MERS? In the studies performed so far, dosage and administration routes were chosen as they have been approved for interferons in the treatment of other diseases, namely chronic viral hepatitis (recombinant interferon alfa) or multiple sclerosis (recombinant interferon beta). Apparently, the investigators did not pay sufficient attention to the acute character of a coronavirus induced pneumonia demonstrating quite different pathological conditions compared to the approved indications, and thus potentially requiring a different treatment approach. To attain a direct antiviral effect with a systemic administration of interferons, high daily doses leading to high serum levels maintained for several days are required as shown, for example, in the treatment of herpes zoster with native interferon alpha or beta [65-67]. With the regimens used in the above mentioned studies as to SARS and MERS, however, only relatively low serum levels of interferons could be achieved.

Which interferon preparation of the already approved ones should be used and how should they be dosed and administered to achieve a therapeutic effect in acute viral infections in general and in coronavirus caused pneumonia in particular? In cell culture experiments, interferon beta is clearly superior to other interferons as to inhibiting replication of coronaviruses $[5,9,37,40,41,45,48,50,68]$. This superiority of interferon beta is also valid for other viruses such as herpes simplex [69]. Accordingly, interferon beta should be the interferon of choice in the treatment of acute viral infections. Regarding the dosage of this type of interferon in acute viral infections, data are available for native interferon beta. 


\section{Native interferon beta in the treatment of acute viral diseases}

In the early 1980s the German competent health authority approved a drug product containing a native interferon beta produced by human fibroblasts (tradename: Fiblaferon ${ }^{\circledR}$ ) for treating acute life-threatening viral diseases such as viral encephalitis and disseminated herpes zoster $[16,67]$. However, the documentation relative to this product is fairly unknown to the international scientific community because the vast majority of clinical data were published in books and/or in German language. Since Fiblaferon ${ }^{\circledR}$ is not marketed anymore, a recombinant interferon beta preparation would be the only available alternative in order to assess if such preparation could also demonstrate beneficial clinical effects in a scenario of an acute viral infection such as coronavirus induced pneumonia. Before suggesting an appropriate therapeutic regimen for a recombinant interferon beta, the data as to the native interferon beta are shortly reported here. Additionally, some unpublished data as to a recombinant $\mathrm{CHO}$-derived interferon beta-1a given by the IV route are provided.

The therapeutically effective regimen for the treatment of acute systemic viral diseases with native interferon beta was developed by Heidemann et al. [70, 71] in immune-compromised patients suffering from herpes zoster. According to the "Heidemann scheme" the native interferon beta is administered in a daily dose of 0.5 million IU per kg body weight (max. 25 million IU per day) as a continuous 24-hour IV infusion for 3-5 consecutive days. The dose for the last day can be given in a ratio of 2:1 spread over two days. On the basis of this treatment schedule, other acute viral diseases including virus encephalitis and virus pneumonia were also successfully treated $[16,67,72,73]$. Due to severe side effects that were frequently observed with this regimen, all patients had to be hospitalized under intensive care conditions. All patients showed high fever and/or other moderate to severe flu-like symptoms. Furthermore, rapid changes of laboratory parameters, especially leukocytopenia, thrombocytopenia and increase of transaminases, required daily laboratory monitoring, including determination of the partial thromboplastin time. All side effects disappeared shortly after termination of treatment. Careful attention had to be paid to fluid balance and fluid substitution. For the infusion, the native interferon beta was dissolved in a body weight dependent volume (up to $500 \mathrm{ml}$ ) of a physiological saline solution plus human albumin.

\section{Proposed dosage of recombinant interferon beta in acute viral infections}

In the late 1980 s clinical pilot studies with a recombinant $\mathrm{CHO}$ derived interferon beta-1a were performed in 15 adult male and female patients suffering from viral hepatitis, viral encephalitis or herpes zoster (data not published). The Heidemann scheme was applied and final daily doses of 50 to $150 \mu \mathrm{g}$ (declared as 10-30 million IU) corresponding to $0.6-2.7 \mu \mathrm{g}$ per $\mathrm{kg}$ individual body weight - were administered. Daily doses of more than $1.3 \mu \mathrm{g}$ interferon beta-1a per $\mathrm{kg}$ body weight could hardly be given for 5 consecutive days due to high fever, leukopenia and/or increase of transaminases. Therapy had to be discontinued prematurely in 2 out of 4 patients who were treated with doses between 1.3 and $1.7 \mu$ g per kg body weight, and in additional 2 out of 2 patients treated with higher dosage. Howev- er, in all 9 patients treated with < $1.3 \mu \mathrm{g}$ per kg body weight therapy could be performed as scheduled. Side effects were very similar to those observed under high dose native interferon beta and also disappeared shortly after termination of treatment.

According to these data, a daily dose of $1.2 \mu \mathrm{g}$ per $\mathrm{kg}$ body weight (max. $90 \mu \mathrm{g}$ per day) seems to be the maximum tolerated dose (MTD) of interferon beta-1a given as a 24-hour continuous IV infusion for 3-5 consecutive days. Thus, relative to the IU the MTD for the recombinant interferon beta-1a is apparently lower than the MTD for the native interferon beta. In juvenile herpes simplex virus encephalitis, a dose of $1.0 \mu \mathrm{g}$ (declared as 0.2 million IU) interferon beta-1 a per $\mathrm{kg}$ body weight (max. $60 \mu \mathrm{g}$ per day) was used as a 24-hour continuous IV infusion and well tolerated but showed no additional therapeutic effect to aciclovir which was given as the basic antiviral treatment [74]. In viral encephalitis, higher dosage of interferon beta- 1 a than in other acute viral diseases might be required due to the repairing activities of interferon beta on the blood-brain barrier which is disturbed in viral encephalitis [75, 76]. Nevertheless, the aforementioned MTD should be widely exploited not only in viral encephalitis but also in other severe acute viral diseases in order to achieve a potential therapeutic effect.

The data about interferon beta composed and analysed here are intended to encourage clinicians to perform clinical studies using recombinant interferon beta- $1 \mathrm{a}$ in severe viral infections with another but probably more appropriate regimen ( $\leq 90 \mu \mathrm{g}$ daily given as a 24-hour continuous IV administration for 3-5 consecutive days) than the approved ones in multiple sclerosis (30 $\mu \mathrm{g} \mathrm{IM}$ once weekly for Avonex ${ }^{\circledR}$ or $44 \mathrm{\mu g}$ SC three times a week for Rebif ${ }^{\circledR}$, respectively). With the suggested regimen, however, more severe and still other adverse drug reactions can occur because of the high daily dose and the IV route of administration.

It has to be emphasized that the proposed dose and regimen is only appropriate for treating acute viral infections and only valid for the non-pegylated recombinant interferon beta-1a but not for other approved recombinant interferon beta preparations, i.e. pegylated interferon beta-1a or E. coli derived interferon beta-1b preparations, where the highest tolerated daily dose - if given as continuous 24-hour IV infusion for 3-5 days - has not yet been determined. A detailed discussion of the comparability of the different interferon beta preparations as well as of the determination of their biological and specific activities is given elsewhere [22, 77, 78].

\section{Feasibility of the proposed interferon beta-1a dosage in coronavirus infections}

Is the regimen proposed for interferon beta-1a in acute viral infections also applicable for treating severe coronavirus infections?

Due to the expected side effects of the proposed regimen for interferon beta-1a in coronavirus infections, only patients with a life-threatening course of their disease will be suitable candidates for this kind of treatment. During severe coronavirus infections, fever, lymphocytopenia and increase of transaminases are often observed [2, 3, 9, 79]. These symptoms may prevent high dose IV administration of interferon beta-1a since they are also common side effects of the proposed therapeutic regimen. Therefore, suitable patients have to be determined at an early stage of their disease, and treatment has to be started when the patients are still in 
a condition and willing to tolerate the side effects mentioned above. It has still to be decided if the MuLBSTA score [80] or another score predicting the risk of mortality in viral pneumonia may be useful to identify such patients.

Furthermore, severe cases of coronavirus infections are characterized by a hyper-inflammatory lung pathology induced by an excessive accumulation of inflammatory cells and high serum levels of pro-inflammatory cytokines (“cytokine storm") [9, 12, 79, 81-84]. In a mouse model as to MERS mouse interferon beta administered via the intranasal route showed opposing effects on this inflammatory response depending on the time of administration. Early treatment with interferon beta on 6 and 24 hours post infection (p.i.), i.e. before peak virus replication occurred, protected mice from fatal outcome, while late treatment on day 2 and 4 p.i., i.e. after peak virus replication, resulted in fatal pneumonia through increased inflammatory cell infiltration in the lungs and enhanced pro-inflammatory cytokine expression [52]. In another mouse model as to MERS, the effects of early and late administered mouse interferon beta given by the SC route were not equally distinct or not found at all [53]. Regarding SARS, experiments were performed with cynomolgus macaques treated with pegylated human interferon alfa-2b administered by the IM route in two different settings: In the prophylactic group the animals received the drug on days $-3,-1,1$, and 3 , in the post exposure group on days 1 and 3 p.i. [39]. Interferon treatment reduced viral replication and pulmonary damage in both groups, even though these effects were more distinct in the prophylactic than in the post exposure group. Protective effects, i.e. prevention of severe inflammation and reduction of mortality, were also observed in other non-human primate models relative to MERS. In these experiments the monkeys (rhesus macaques or common marmosets, respectively) received human interferon alfa- 2 b or beta- $1 \mathrm{~b}$, respectively, by the SC route. The initial dose was administered 8 hours p.i. followed by further one to three doses until 56 hours p.i., i.e. in these models all doses were given prior to the peak of clinical signs and viral loads [47, 49]. Taken together, the results obtained in animal models also indicate that interferon treatment of coronavirus infected patients should be started at an early stage of their disease in order to achieve a potential protective effect because a (too) late initiation of interferon treatment is possibly not only therapeutically ineffective but can even lead to an exacerbation of the disease.

As to humans, there are no data available how high doses of interferon beta-1a given by the IV route act on an exaggerated inflammation. In the treatment of multiple sclerosis with interferon beta, it is assumed that an anti-inflammatory effect of this cytokine is obtained by the approved IM or SC administration of medium doses [85]. In contrast, during local, i.e. intralesional, treatment of basal cell carcinoma with low doses of interferon beta-1a, often an inflammation of the lesion is induced before subsequent healing [86]. Similar observations were made after intralesional treatment of melanoma metastases with low doses of interferon beta-1a [32]. Accordingly, interferon beta can have anti-inflammatory and proinflammatory effects depending on the disease (stage), dosage and administration route. A dual mode of action in inflammation is also known for interferon gamma [13, 14, 28].
Relative to the infections with the novel coronavirus SARS-CoV-2, it will be interesting to learn the results of interferon studies planned or just started in China (ClinicalTrials.gov, search terms: "coronavirus" and "interferon"). In some of these studies, the patients receive a recombinant interferon alfa or beta preparation via oral spray or inhalation, respectively, possibly leading to a much higher drug concentration in the affected organ than with the "standard" SC or IM administration of different interferons previously used in SARS and MERS (see above). In a patient with COVID-19, however, the inhalation of interferon alfa-2b given together with lopinavir and ritonavir tablets did not prevent his lethal outcome [84].

\section{Concluding remarks}

The therapeutic role that interferons can play in the treatment of coronavirus infections has still to be determined. Interferons are potent inhibitors of virus replication as shown in several cell culture and animal experiments (see above). Thus, interferons have been used and should also further be considered in the treatment of coronavirus infections. However, due to their pleiotropic effects and possible different actions depending to a large extent on the immune status, the outcome of any clinical application of interferons is often hard to predict $[18,21]$.

The relevance of results elaborated in cell culture or animal models needs to be scrutinized relative to various factors with impact on the specific clinical scenario. For example, the window for a supposed successful therapeutic administration of interferon after onset of symptoms but prior to the peak of virus replication is very different in humans and experimentally infected mice or monkeys. Furthermore, the peak for virus replication is generally unknown in patients. Also the comparison of the results obtained in one animal model with those found in another one is difficult due to differences in animal species, delivery route, dose, start, frequency and duration of administration, interferon subtype and/or active viral antagonism of innate immunity $[52,53]$. In addition, there are still further aspects to be considered if findings in the different animal models studying antivirals for coronavirus infections are assessed [87].

A therapeutic regimen successfully used with an interferon in one human disease might not be effective or tolerated in another one or another stage of the disease. That could be the reason for the reported failure of interferon treatment in SARS and MERS where low-dose and medium-dose regimens were applied as approved for virus hepatitis and multiple sclerosis. In the past, high-dosed native interferon beta given by the IV route was successfully used for the treatment of various acute viral diseases. As to recombinant interferon beta-1a the MTD for a high dose IV administration has already been determined. It remains an open question if this dosage is therapeutically effective in severe coronavirus infections and if it can safely be applied in patients with a poor survival prognosis at an early stage of their disease.

\section{Conflict of Interest}

The authors declare that they have no conflict of interest. 


\section{References}

[1] World Health Organization. WHO characterizes COVID-19 as a pandemic. Rolling updates on coronavirus disease (COVID-19) 11 March 2020; https://www.who.int/emergencies/diseases/novelcoronavirus-2019/events-as-they-happen

[2] Chen N, Zhou M, Dong X et al. Epidemiological and clinical characteristics of 99 cases of 2019 novel coronavirus pneumonia in Wuhan, China: A descriptive study. Lancet 2020; 395: 507-513

[3] Guan W], Ni ZY, Hu Y et al. Clinical characteristics of coronavirus disease 2019 in China. N Engl J Med 2020; doi:10.1056/NEJMoa2002032

[4] Mahase E. Coronavirus: Covid-19 has killed more people than SARS and MERS combined, despite lower case fatality rate. BMJ 2020; 368: m641

[5] Zumla A, Chan JF, Azhar El et al. Coronaviruses - drug discovery and therapeutic options. Nat Rev Drug Discov 2016; 15: 327-347

[6] Li G, De Clercq E. Therapeutic options for the 2019 novel coronavirus (2019-nCoV). Nat Rev Drug Discov 2020; doi.org/10.1038/d41573020-00016-0

[7] World Health Organization. WHO R\&D Blueprint: Informal consultation on prioritization of candidate therapeutic agents for use in nove coronavirus 2019 infection. Geneva, Switzerland, 24 January 2020 https://apps.who.int/iris/handle/10665/330680

[8] Baron S, Coppenhaver DH, Dianzani F et al. Introduction to the interferon system. In: Baron S, Coppenhaver DH, Dianzani F, Fleischmann Jr WR, Hughes TK, Klimpel GR, Niesel DW, Stanton G], Tyring SK, Eds. Interferon: Principles and Medical Applications. Galveston, TX: The University of Texas Medical Branch at Galveston Department of Microbiology; 1992: 1-15

[9] Cheng VCC, Lau SKP, Woo PCY et al. Severe acute respiratory syndrome coronavirus as an agent of emerging and reemerging infection. Clin Microbiol Rev 2007; 20: 660-694

[10] Kindler E, Thiel V, Weber F. Interaction of SARS and MERS coronaviruses with the antiviral interferon response. Adv Virus Res 2016; 96: 219-243

[11] Trinchieri G. Type I interferon: Friend or foe? J Exp Med 2010; 207: 2053-2063

[12] Totura AL, Baric RS. SARS coronavirus pathogenesis: Host innate immune responses and viral antagonism of interferon. Curr Opin Virol 2012; $2: 264-275$

[13] Brzoska J, Obert HJ. Interferon gamma: ein janusköpfiger Mediator bei Entzündungen. Drug Res 1987; 37: 1410-1416

[14] Brzoska J, Obert HJ. Immunomodulating effects of interferons: Conclusions for therapy. In: Gross G, Jablonska S, Pfister H, Stegner HE, Eds. Genital Papillomavirus Infections. Berlin, Heidelberg: Springer; 1990: 379-391

[15] Lazear HM, Schoggins JW, Diamond MS. Shared and distinct functions of type I and type III interferons. Immunity 2019; 50: 907-923

[16] Hündgen M, von Eick H. Interferone. Grundlagen und Anwendung in Klinik und Praxis. Med Monatsschr Pharm 1991; 14: 164-173

[17] Friedman RM. Clinical uses of interferons. Br J Clin Pharmacol 2007; 65: $158-162$

[18] Antonelli G, Scagnolari C, Moschella F et al. Twenty-five years of type I interferon-based treatment: A critical analysis of its therapeutic use. Cytokine Growth Factor Rev 2015; 26: 121-131

[19] Li SF, Gong MJ, Zhao FR et al. Type I interferons: Distinct biological activities and current applications for viral infection. Cell Physiol Biochem 2018; 51: 2377-2396

[20] Stewart WE II. The Interferon System. Wien, New York: Springer; 1981
[21] Brzoska J. Interferon gamma in cinical use: review of indications. In: Hollenberg CP, Sahm H, Eds. Therpeutics, Diagnostics, New Vaccines, Interferon Treatment and Plasma Proteins (BIOTEC 4). Stuttgart, Jena, New York: Gustav Fischer; 1992: 109-115

[22] Obert H], Pöhlau D. Beta-Interferon. Schwerpunkt Multiple Sklerose. Berlin, Heidelberg, New York: Springer; 2000

[23] Borden EC, Sen GC, Uze G et al. Interferons at age 50: past, current and future impact on biomedicine. Nat Rev Drug Discov 2007; 6 : 975-990

[24] Bracarda S, Eggermont AM, Samuelsson J. Redefining the role of interferon in the treatment of malignant diseases. Eur J Cancer 2010; 46: 284-297

[25] Ni L, Lu J. Interferon gamma in cancer immunotherapy. Cancer Med 2018; 7: 4509-4516

[26] Aricò E, Castiello L, Capone I et al. Type I interferons and cancer: an evolving story demanding novel clinical applications. Cancers 2019; 11: 1943

[27] Bocci V. Pharmacokinetics of interferons and routes of administration. In: Baron S, Coppenhaver DH, Dianzani F, Fleischmann Jr WR, Hughes TK, Klimpel GR, Niesel DW, Stanton G], Tyring SK, Eds. Interferon: Principles and Medical Applications. Galveston, TX: The University of Texas Medical Branch at Galveston Department of Microbiology; 1992: 417-425

[28] Mühl H, Pfeilschifter J. Anti-inflammatory properties of pro-inflammatory interferon-y. Int Immunopharmacol 2003; 3: 1247-1255

[29] Hündgen M. Pharmakologie der Interferone -alpha, -beta und -gamma. In: Schmoll HJ, Schöpf E, Eds. Lokale und systemische Tumortherapie mit Interferonen (Aktuelle Immunologie 5). München, Bern, Wien, San Francisco: W Zuckschwerdt; 1988: 5-16

[30] Hündgen $\mathrm{M}$, von Eick $\mathrm{H}$. Pharmakologie von Interferonen (IFN- $\alpha$, IFN- $\beta$, IFN- $\gamma$ ). In: Orfanos CE, Garbe C, Eds. Das maligne Melanom der Haut. München, Bern, Wien, San Francisco: W Zuckschwerdt; 1990: 243-247

[31] Fierlbeck G, Schiebel U, Bruchelt G et al. Pharmacokinetic and immunological investigations in patients treated with recombinant interferon beta. J Interferon Res 1990; 10 Suppl 1: 126 (Abstract)

[32] Fierlbeck G, d'Hoedt B, Stroebel W et al. Intraläsionale Therapie von Melanommetastasen mit rekombinantem Interferon- $\beta$. Hautarzt 1992; 43: $16-21$

[33] Fierlbeck G, Ulmer A, Schreiner T et al. Pharmacodynamics of recombinant IFN- $\beta$ during long-term treatment of malignant melanoma. J Interferon Cytokine Res 1996; 16: 777-781

[34] Foster GR. Review article: Pegylated interferons: chemical and clinical differences. Aliment Pharmacol Ther 2004; 20: 825-830

[35] Cocco E, Marrosu MG. Profile of PEGylated interferon beta in the treatment of relapsing-remitting multiple sclerosis. Ther Clin Risk Manag 2015; 11: 759-766

[36] Brzoska J. Topische Interferonpräparationen bei dermatologischen Erkrankungen. In: Gross G, Bröcker EB, Eds. Interferon-Therapie in der Dermatologie (Aktuelle Immunologie 11). München, Bern, Wien, San Francisco: W Zuckschwerdt; 1994: 1-9

[37] Cinatl J, Morgenstern B, Bauer G et al. Treatment of SARS with human interferons. Lancet 2003; 362: 293-294

[38] Chen F, Chan KH, Jiang Y et al. In vitro susceptibility of 10 clinical isolates of SARS coronavirus to selected antiviral compounds. J Clin Virol 2004; 31: 69-75

[39] Haagmans BL, Kuiken T, Martina BE et al. Pegylated interferon- $\alpha$ protects type 1 pneumocytes against SARS coronavirus infection in macaques. Nat Med 2004; 10: 290-293

[40] Scagnolari C, Vicenzi E, Bellomi F et al. Increased sensitivity of SARS-coronavirus to a combination of human type I and type II interferons. Antivir Ther 2004; 9: 1003-1011 
[41] Spiegel M, Pichlmair A, Mühlberger E et al. The antiviral effect of interferon-beta against SARS-coronavirus is not mediated by MxA protein. J Clin Virol 2004; 30: 211-213

[42] Zheng B, He ML, Wong KL et al. Potent inhibition of SARS-associated coronavirus ( $\mathrm{SCOV}$ ) infection and replication by type I interferons (IFN- $\alpha / \beta$ ) but not by type II interferon (IFN- $\gamma$ ). J Interferon Cytokine Res 2004; 24: 388-390

[43] Ströher U, DiCaro A, Li Y et al. Severe acute respiratory syndromerelated coronavirus is inhibited by interferon- $\alpha$. J Infect Dis 2004; 189 : 1164-1167

[44] Morgenstern B, Michaelis M, Baer PC et al. Ribavirin and interferon- $\beta$ synergistically inhibit SARS-associated coronavirus replication in animal and human cell lines. Biochem Biophys Res Commun 2005; 326: 905-908

[45] Dahl H, Linde A, Strannegård Ö. In vitro inhibition of SARS virus replication by human interferons. Scand J Infect Dis 2004; 36 : 829-831

[46] Falzarano D, de Wit E, Martellaro $C$ et al. Inhibition of novel $\beta$ coronavirus replication by a combination of interferon- $\alpha 2 b$ and ribavirin. Sci Rep 2013; 3: 1686

[47] Falzarano D, de Wit E, Rasmussen AL et al. Interferon- $\alpha 2 b$ and ribavirin treatment improves outcome in MERS-CoV-infected rhesus macaques. Nat Med 2013; 19: 1313-1317

[48] Chan JFW, Chan KH, Kao RYT et al. Broad-spectrum antivirals for the emerging Middle East respiratory syndrome coronavirus. J Infect 2013; 67: 606-616

[49] Chan JFW, Yao Y, Yeung ML et al. Treatment with lopinavir/ritonavir or interferon- $\beta 1 \mathrm{~b}$ improves outcome of MERS-CoV infection in a nonhuman primate model of common marmoset. J Infect Dis 2015; 212: 1904-1913

[50] Hart B], Dyall J, Postnikova E et al. Interferon- $\beta$ and mycophenolic acid are potent inhibitors of Middle East respiratory syndrome coronavirus in cell-based assays. J Gen Virol 2014; 95: 571-577

[51] Li HS, Kuok DIT, Cheung MC et al. Effect of interferon alpha and cyclosporine treatment separately and in combination on Middle East respiratory syndrome coronavirus (MERS-CoV) replication in a human in-vitro and ex-vivo culture model. Antiviral Res 2018; 155: 89-96

[52] Channappanavar R, Fehr AR, Zheng J et al. IFN-I response timing relative to virus replication determines MERS coronavirus infection outcomes. J Clin Invest 2019; 129: 3625-3639

[53] Sheahan TP, Sims AC, Leist SR et al. Comparative therapeutic efficacy of remdesivir and combination lopinavir, ritonavir, and interferon beta against MERS-CoV. Nat Commun 2020; 11: 222. doi.org/10.1038/ s41467-019-13940-6

[54] Loutfy MR, Blatt LM, Siminovitch KA et al. Interferon alfacon-1 plus corticosteroids in severe acute respiratory syndrome: A preliminary study. JAMA 2003; 290: 3222-3228

[55] Zhao Z, Zhang F, Xu M et al. Description and clinical treatment of an early outbreak of severe acute respiratory syndrome (SARS) in Guangzhou, PR China. J Med Microbiol 2003; 52: 715-720

[56] Al-Tawfiq JA, Momattin H, Dib J et al. Ribavirin and interferon therapy in patients infected with the Middle East respiratory syndrome coronavirus: An observational study. Int J Infect Dis 2014; 20: 42-46

[57] Shalhoub S, Farahat F, Al-jiffri A et al. IFN- $\alpha 2$ a or IFN- $\beta 1$ a in combination with ribavirin to treat Middle East respiratory syndrome coronavirus pneumonia: A retrospective study. J Antimicrob Chemother 2015; 70: 2129-2132

[58] Omrani AS, Saad MM, Baig K et al. Ribavirin and interferon alfa-2a for severe Middle East respiratory syndrome coronavirus infection: A retrospective cohort study. Lancet Infect Dis 2014; 14: 1090-1095
[59] Arabi YM, Alothman A, Balkhy HH et al. Treatment of Middle East respiratory syndrome with a combination of lopinavir-ritonavir and interferon- $\beta 1 \mathrm{~b}$ (MIRACLE trial): Study protocol for a randomized controlled trial. Trials 2018; 19: 81

[60] Cheng VCC, Tang BSF, Wu AKL et al. Medical treatment of viral pneumonia including SARS in immunocompetent adult. J Infect 2004; 49: $262-273$

[61] Stockman L], Bellamy R, Garner P. SARS: Systematic review of treatment effects. PLoS Med 2006; 3: e343. doi: 10.1371/journal. pmed.0030343

[62] Wong SSY, Yuen KY. The management of coronavirus infections with particular reference to SARS. J Antimicrob Chemother 2008; 62: 437-441

[63] Morra ME, Van Thanh L, Kamel MG et al. Clinical outcomes of current medical approaches for Middle East respiratory syndrome: A systematic review and meta-analysis. Rev Med Virol 2018; 28: e1977

[64] Momattin H, Al-Ali AY, Al-Tawfiq JA. A systematic review of therapeutic agents for the treatment of the Middle East respiratory syndrome coronavirus (MERS-CoV). Travel Med Infect Dis 2019; 30: 9-18

[65] Merigan TC, Rand KH, Pollard RB et al. Human leukocyte interferon for the treatment of herpes zoster in patients with cancer. N Engl J Med 1978; 298: 981-987

[66] Merigan TC, Gallagher JG, Pollard RB et al. Short-course human leukocyte interferon in treatment of herpes zoster in patients with cancer. Antimicrob Agents Chemother 1981; 19: 193-195

[67] Heidemann E, Obert HJ. Clinical trials and pilot studies with natural interferons in Germany. In: Kirchner H, Schellekens H, Eds. The Biology of the Interferon System 1984. Amsterdam, New York, Oxford: Elsevier; 1985: 557-567

[68] Haagmans BL, Osterhaus ADME. Coronaviruses and their therapy. Antiviral Res 2006; 71: 397-403

[69] Domke-Opitz I, Straub P, Kirchner H. Effect of interferon on replication of herpes simplex virus types 1 and 2 in human macrophages. J Virol 1986; 60: 37-42

[70] Heidemann E, Wilms K, Treuner ] et al. Fibroblasten-Interferon zur Behandlung des Herpes zoster. Eine Pilotstudie. Dtsch Med Wochenschr 1982; 107: 695-697

[71] Heidemann E, Dietz K, Obert HJ et al. Günstigerer Verlauf des Herpes zoster bei immunsupprimierten Patienten unter Behandlung mit Fibroblasteninterferon. Onkologie 1984; 7: 210-212

[72] Hündgen M. Klinische Erfahrungen mit natürlichem Interferon-beta. In: Hofschneider PH, Ed. Ergebnisse der Beta-Interferon-Therapie bei chronisch-aktiver Hepatitis B, Multipler Sklerose und Krebserkrankungen (Aktuelle Immunologie 3). München, Bern, Wien, San Francisco: W Zuckschwerdt; 1988: 45-50

[73] Wintergerst U, Belohradsky BH. Acyclovir monotherapy versus acyclovir plus beta-interferon in focal viral encephalitis in children. Infection 1992; 20: 207-212

[74] Wintergerst U, Kugler K, Harms F et al. Therapy of focal viral encephalitis in children with aciclovir and recombinant beta-interferon - results of a placebo-controlled multicenter study. Eur J Med Res 2005; 10: 527-531

[75] Daniels BP, Klein RS. Knocking on closed doors: Host interferons dynamically regulate blood-brain barrier function during viral infections of the central nervous system. PLoS Pathog 2015; 11: e1005096

[76] Bhat H, Lang KS, Hardt C et al. Interferon in the CNS. Neurosignals 2019; 27 (S1): 44-53

[77] Antonetti F, Finocchiaro O, Mascia M et al. A comparison of the biologic activity of two recombinant IFN-beta preparations used in the treatment of relapsing-remitting multiple sclerosis. J Interferon Cytokine Res 2002; 22: 1181-1184 
[78] Scagnolari C, Selvaggi C, Di Biase E et al. In vitro assessment of the biologic activity of interferon beta formulations used for the treatment of relapsing multiple sclerosis. J Immunoassay Immunochem 2014; 35 : 288-299

[79] Huang C, Wang Y, Li X et al. Clinical features of patients infected with 2019 novel coronavirus in Wuhan, China. Lancet 2020; 395: 497-506

[80] Guo L, Wei D, Zhang X et al. Clinical features predicting mortality risk in patients with viral pneumonia: The MuLBSTA score. Front Microbiol 2019; 10. doi:10.3389/fmicb.2019.02752

[81] Ward SE, Loutfy MR, Blatt LM et al. Dynamic changes in clinical features and cytokine/chemokine responses in SARS patients treated with interferon alfacon-1 plus corticosteroids. Antivir Ther 2005; 10: 263-275

[82] Kindler E, Thiel V. SARS-CoV and IFN: too little, too late. Cell Host \& Microbe 2016; 19: 139-141
[83] Channappanavar R, Perlman S. Pathogenic human coronavirus infections: Causes and consequences of cytokine storm and immunopathology. Semin Immunopathol 2017; 39: 529-539

[84] Xu Z, Shi L, Wang Y et al. Pathological findings of COVID-19 associated with acute respiratory distress syndrome. Lancet Respir Med 2020; doi. org/10.1016/S2213-2600(20)30076-X

[85] Kieseier BC. The mechanism of action of interferon- $\beta$ in relapsing multiple sclerosis. CNS Drugs 2011; 25: 491-502

[86] Kowalzick L, Rogozinski T, Schober $C$ et al. Treatment of basal cell carcinoma with intralesional recombinant interferon beta: A dose-finding study. Eur J Dermatol 1994; 4: 430-433

[87] Totura AL, Bavari S. Broad-spectrum coronavirus antiviral drug discovery. Expert Opin Drug Discov 2019; 14: 397-412 